\title{
Plexus brachialis-nerveblokade
}

\author{
En effektiv aksillær blokade av plexus brachialis krever flere injeksjoner \\ der innføring av et kateter i proksimal rening er fordelaktig.
}

Regionalanestesi av plexus brachialis i armhulen blir ofte brukt ved operasjon i albue, underarm og hånd. Ved denne teknikken kan pasienten unngå narkose. Det er spesielt viktig for eldre pasienter at en narkosebetinget reduksjon av kognitive funksjoner blir forhindret. Pasientens sikkerhet økes også ved at den respirasjonshemmende bivirkningen av opiatene bortfaller. Kontinuerlig regionalanestesi via et kateter kan holde pasienten smertefri etter operasjonen. Pasienten kan videre være lettere å mobilisere etter operasjonen dersom regionalanestesi brukes. Et hovedproblem med aksillær blokade har vært å få bedøvelsen effektiv nok.

I mitt doktorgradsarbeid ble effekten av bedøvelsen for tre forskjellige blokademetoder i armhulen klinisk testet. Spredningsmønsteret for bedøvelsesmidlet ble evaluert med MR-undersøkelse. Vi undersøkte spesielt om forskjellen i klinisk effekt av bedøvelsen kunne forklares ut fra spredningsmønsteret vist ved MR-undersøkelsen.

Avhandlingen viser at min egen metode med tre injeksjoner hadde raskere og bedre blokadeeffekt sammenlignet med de to andre metodene. Denne forskjellen var sammenfallende med MR-funnene.

Metoden med tre injeksjoner er å foretrekke og kan gjennomføres med eller uten moderne hjelpemidler som nervestimulator og ultralyd. Den passer derfor inn i alt fra primitive til moderne helsesystemer.

trygve.kjelstrup@labmed.uio.no

\section{Trygve Kjelstrup}

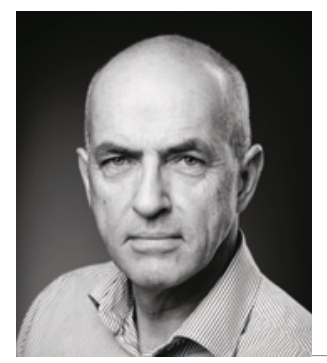

Trygve Kjelstrup. Foto: Øystein H. Horgmo

Disputas

Trygve Kjelstrup disputerte for ph.d.-graden ved Universitetet i Oslo 15. november 2016 Tittelen på avhandlingen er Evaluation of a multiple injection axillary block technique by clinical assessment and MRI

\section{Epilepsi hos blivende foreldre}

\section{Hos blivende foreldre med epilepsi er det funnet økt forekomst av psy- kiske helseplager og lavere livskvalitet.}

Epilepsi finnes i alle aldersgrupper og er assosiert med økt risiko for sosioøkonomiske og psykiske problemer. Selv om disse utfordringene er velkjente er det svært få studier med søkelys på gravide kvinner med epilepsi - og ingen studier på blivende fedre med epilepsi. Med bakgrunn i dette ønsket vi å kartlegge psykososiale forhold og livskvalitet før, under og etter svangerskap hos personer med epilepsi.

Mitt doktorgradsarbeid består av epidemiologiske tverrsnittstudier basert på selvrapporterte data fra Den norske mor-ogbarn-undersøkelsen (MoBa), supplert med helseopplysninger fra Medisinsk fødselsregister. Fra 102000 fødsler registrert på ca. 95000 kvinner og 76000 menn, identifiserte vi henholdsvis ca. 700 kvinner og 650 menn med epilepsi. Referansegruppene var alle uten epilepsi. Kvinnene ble fulgt opp også etter svangerskapet.
Epilepsi var assosiert med høyere forekomst av psykiatriske diagnoser og symptomer før, under og etter svangerskapet. Symptom-skår-diagnoser viste en mye høyere prevalens enn selvrapporterte diagnoser, noe som kan indikere en underrapportering eller underdiagnostisering av psykiatrisk sykdom. Uplanlagt graviditet, langtidssykmelding og samlivsbrudd var blant forhold assosiert med epilepsi. Livskvalitet og selvtillit var lavere hos kvinner og menn med epilepsi under og etter svangerskapet.

Ut fra våre funn synes vi det er viktig å identifisere utfordringer hos personer med epilepsi i forkant av graviditet, for å sikre adekvat oppfølging videre. Kartlegging av symptomer og sosioøkonomiske forhold med spørreskjema er et enkelt tiltak.

\section{Simone Frizell Reiter}

simonfreiter@gmail.com

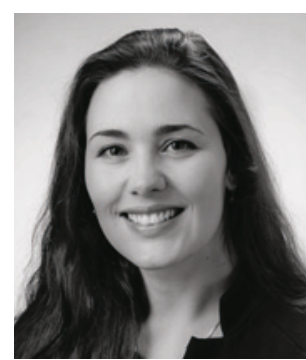

Simone Frizell Reiter. Foto: Anne Sidsel Herdlevær

\section{Disputas}

Simone Frizell Reiter disputerte for ph.d.graden ved Universitetet i Bergen 11. november 2016. Tittelen på avhandlingen er Psychiatric disease, adverse social aspects and quality of life in women and men with epilepsy related to pregnancy. 